\title{
Bacteria, not archaea, restore nitrification in a zinc-contaminated soil
}

\author{
Jelle Mertens ${ }^{1}$, Kris Broos ${ }^{2,5}$, Steven A Wakelin², George A Kowalchuk ${ }^{3,4}$, Dirk Springael ${ }^{1}$ \\ and Erik Smolders ${ }^{1}$ \\ ${ }^{1}$ Division of Soil and Water Management, Katholieke Universiteit Leuven, Heverlee, Belgium; ${ }^{2}$ CSIRO Land \\ and Water, Environmental Biogeochemistry Program, Glen Osmond, South Australia, Australia; ${ }^{3}$ Centre for \\ Terrestrial Ecology, Netherlands Institute of Ecology, Heteren, The Netherlands and ${ }^{4}$ Institute of Ecological \\ Science, Free University of Amsterdam, Amsterdam, The Netherlands
}

\begin{abstract}
Biological ammonia oxidation had long been thought to be mediated solely by discrete clades of $\beta$ - and $\gamma$-proteobacteria (ammonia-oxidizing bacteria; AOB). However, ammonia-oxidizing Crenarchaeota (ammonia-oxidizing archaea; AOA) have recently been identified and proposed to be the dominant agents of ammonia oxidation in soils. Nevertheless, the dynamics of AOB versus AOA, and their relative contribution to soil ammonia oxidation and ecosystem functioning on stress and environmental perturbation, remain unknown. Using a 3-year longitudinal field study and the amoA gene as a molecular marker, we demonstrate that $A O B$, but not AOA, mediate recovery of nitrification after zinc $(\mathrm{Zn})$ contamination. Pristine soils showed approximately equal amoA gene copy numbers and transcript levels for AOB and AOA. At an intermediate $\mathrm{Zn}$ dose (33.7 mmol $\mathrm{Zn}$ per $\mathrm{kg}$ ), ammonia oxidation was completely inhibited, and the numbers of $A O B$ and $A O A$ amoA gene copies and gene transcripts were reduced. After 2 years, ammonia oxidation in the field soils was fully restored to preexposure levels, and this restoration of function was concomitant with an increase of $A O B$ amoA gene copy and gene transcript numbers. Analysis of the restored community revealed domination by a phylogenetically distinct Zn-tolerant Nitrosospira sp. community. In contrast, the numbers of AOA amoA gene copies and gene transcripts remained 3- and $10^{4}$-fold lower than recovered AOB values, respectively. Thus, although recent findings have emphasized a dominant role of archaea in soil-borne ammonia oxidation, we demonstrate that a phylogenetic shift within the AOB community drives recovery of nitrification from $\mathrm{Zn}$ contamination in this soil.
\end{abstract}

The ISME Journal (2009) 3, 916-923; doi:10.1038/ismej.2009.39; published online 23 April 2009

Subject Category: microbial population and community ecology

Keywords: amoA; nitrification; zinc-contaminated soil; zinc tolerance; heavy metals

\section{Introduction}

Nitrification is an important process in the global nitrogen $(\mathrm{N})$ cycle, oxidizing ammonia to nitrate and providing substrate for reductive nitrogen processes (denitrification). The rate-limiting step in nitrification is the oxidation of ammonia to nitrite, with nitrite typically being rapidly oxidized to nitrate by nitrite-oxidizing organisms. Until recently, ammonia oxidation has been considered to be entirely mediated through activities of ammonia-oxidizing bacteria (AOB; Kowalchuk and Stephen, 2001). Cultivation-dependent (Head et al., 1993), and subsequently cultivation-independent studies

Correspondence: J Mertens, Division of Soil and Water Management, Katholieke Universiteit Leuven, Kasteelpark Arenberg 20, Heverlee, 3001, Belgium.

E-mail: jelle.mertens@ees.kuleuven.be

${ }^{5}$ Current address: VITO-Flemish Institute for Technological Research, Boeretang 200, $2400 \mathrm{Mol}$, Belgium

Received 15 September 2008; revised 17 March 2009; accepted 23 March 2009; published online 23 April 2009
(Stephen et al., 1996, 1998), had suggested that members of a distinct clade of $\beta$-proteobacteria were the primary biological agents of ammonia oxidation in soil. The narrow phylogenetic breadth of this group facilitated the design of primers to monitor AOB using both phylogenetic (rRNA) and functional gene (amoA encoding the $\alpha$-subunit of the key enzyme ammonia monooxygenase) markers (Rotthauwe et al., 1997; Kowalchuk et al., 2000; Kowalchuk and Stephen, 2001). Using these nucleic acid-based tools, there have been extensive environmental and ecotoxicological studies exploring the distribution, diversity and response to environmental stresses of AOB in relationship with soil nitrification (for example, Koops et al., 2001; Kowalchuk and Stephen, 2001; Aoi et al., 2004).

Recently, Venter et al. (2004) and Treusch et al. (2005) suggested the involvement of archaea in the global nitrification process. This genetic potential for archaeal ammonia oxidation was soon supported by the cultivation of an ammonia-oxidizing archaea isolate (AOA; Francis et al., 2005; Könneke et al., 
2005), and it became evident that the pool of amoA genes across a range of soils appeared archaeadominated (1.5-230 times > AOB; Leininger et al., 2006). Analysis of amoA mRNA copy levels also suggested that Crenarchaeota are the most active ammonia-oxidizing organisms in several soils (Leininger et al., 2006). These recent findings have resulted in a fundamental shift in our understanding of the biology underpinning nitrification in environmental samples (Francis et al., 2007). In particular, the current ethos is for an archaeal driven process, questioning the wider role of bacteria in this key N-cycle process in soil (Leininger et al., 2006; Nicol and Schleper, 2006; He et al., 2007).

The biological oxidation of ammonia can be influenced by numerous factors and is recognized as being a model process for ecological studies (Kowalchuk and Stephen, 2001). Although numerous studies have explored the links between environmental factors, AOB and nitrification, the response of AOA to environmental perturbations remains unknown (Nicol and Schleper, 2006; Francis et al., 2007; Boyle-Yarwood et al., 2008; Chen et al., 2008; Shen et al., 2008).

Soil nitrification is highly sensitive to elevated zinc (Zn; Smolders et al., 2004), although ecotoxicological effects can be transient (Rusk et al., 2004). It has been hypothesized that recovery of nitrification following $\mathrm{Zn}$ exposure is due to the development of Zn-tolerant AOB populations (Mertens et al., 2006). However, the recent insights into the role of AOA in soil ammonia oxidation (Leininger et al., 2006) place the role of AOB in nitrification restoration in doubt.

Here, we report the relative responses of $\mathrm{AOB}$ and AOA during the recovery of the ammonia oxidation process in an Australian agricultural soil (Spalding, South Australia) after experimental Zn contamination. To examine whether the functional recovery was due to changes in the size, activity or composition of dominant AOB and/or AOA, we measured the numbers of amoA gene copies and gene transcripts and assessed the amoA community composition for both $\mathrm{AOB}$ and AOA populations, and compared the data to patterns of ammonia oxidation activity.

\section{Materials and methods}

Soil treatment and nitrification

Top soil was sampled from an ongoing field trial in Spalding, South Australia, within 1 week after $\mathrm{ZnSO}_{4}$ addition (T0) and annually for 3 years (T1T3). The Spalding soil is classified as a chromosol (Isbell, 1996), and has a $\mathrm{pH}\left(0.01 \mathrm{M} \mathrm{CaCl}_{2}\right)$ of 6.3 , $1.9 \%$ organic carbon and $27 \%$ clay. The background $\mathrm{Zn}$ concentration is $0.9 \mathrm{mmol} \mathrm{Zn}$ per $\mathrm{kg}$. Zinc treatments were duplicated, and metal salts were incorporated into the soil using a rotary hoe. At each sampling, four topsoil samples $(0-10 \mathrm{~cm})$ were collected per plot using a 5-cm-diameter auger, and samples were combined to yield one mixed sample. Details about the experimental design, the spiking procedure, soil sampling and soil physicochemical properties have been reported previously (Broos et al., 2007b). Nine Zn treatments were imposed; a control soil ('unexposed soil') and 8 soils which received increasing Zn doses (1.1-113 mmol Zn per $\mathrm{kg}$ ). After sampling, soils were air dried, ground, sieved to $<2 \mathrm{~mm}$ and stored in closed containers at room temperature. Before further functional and molecular analysis, soils were remoistened with distilled water to $50 \%$ of the maximum waterholding capacity and aerobically incubated at $20^{\circ} \mathrm{C}$ for 14 days in the dark to minimize the effects of storage time and of temperature and moisture content at the time of sampling.

Substrate induced nitrification (SIN) was measured in all Zn treatments (that is, the unexposed soil sample and 8 soil samples with increasing $\mathrm{Zn}$ doses) at T0 to T3 in duplicate per soil sample, and SIN was expressed as the percentage $\mathrm{NH}_{4}^{+}$substrate used (\%) 28 days after substrate addition (100 mg $\mathrm{NH}_{4}^{+}-\mathrm{N}$ per kg soil; Broos et al., 2007b). Effects of increasing $\mathrm{Zn}$ concentrations on the nitrification process were related to $\mathrm{Zn}$ concentrations in a $\mathrm{CaCl}_{2}$ soil extract. Total $\mathrm{Zn}$ concentrations in the $\mathrm{CaCl}_{2}$ extract ranged from 0.01 to $109 \mathrm{mM} \mathrm{Zn}$ at To and 0.01 to $21 \mathrm{mM} \mathrm{Zn}$ at $\mathrm{T} 2$. The plot that received $28.3 \mathrm{mmol} \mathrm{Zn}$ per $\mathrm{kg}$, corresponding to $22 \mathrm{mM} \mathrm{Zn}$ in a $\mathrm{CaCl}_{2}$ soil extract at $\mathrm{T} 0$ and $6.6 \mathrm{mM} \mathrm{Zn}$ in a $\mathrm{CaCl}_{2}$ soil extract at T2 ('Zn-exposed soil'), represented the largest $\mathrm{Zn}$ dose at which soil nitrification fully recovered following initial inhibition.

\section{Zn-tolerance testing}

$\mathrm{Zn}$ tolerance was tested in the unexposed and the Zn-exposed soil samples at T0 to T3 using the spikeon-spike test of Mertens et al. (2006). In short, $\mathrm{ZnCl}_{2}$ was added to duplicate suspensions of soil samples (1:10 soil $/ \mathrm{CaCl}_{2} 0.01 \mathrm{M}$ ratio) to final concentrations of $0,0.77,1.5$ and $3.1 \mathrm{mM}$ added $\mathrm{Zn}$. Ammonium sulfate was added at $0.7 \mathrm{mM} \mathrm{NH}_{4}-\mathrm{N}$, and the $\mathrm{pH}$ in suspension was adjusted immediately after ammonia addition and daily during the 3-day test to $\mathrm{pH}$ 5.8 using $0.1 \mathrm{M} \mathrm{NaOH}$ or $\mathrm{HCl}$. We preferred to adjust $\mathrm{pH}$ to $\mathrm{pH} 5.8$ to approach the in situ soil $\mathrm{pH}$ rather than the optimal $\mathrm{pH}$ for nitrification (that is, $\mathrm{pH} 7-8$; Jiang and Bakken, 1999). The potential nitrification rate (PNR; Smolders et al., 2001) was measured, and is the nitrate production rate in the initial period (0-7 days) after ammonia addition (mg $\mathrm{NO}_{3}^{-}$$\mathrm{N}$ per $\mathrm{kg}$ per day) during which there is unlimited substrate present. The experimental setup for SIN and PNR is essentially identical, but whereas the SIN is defined as the amount of substrate used within a 28-day incubation experiment (during which the substrate may have already been exhausted-note that SIN never exceeds $100 \%$ ), PNR is defined as the rate of substrate used over a shorter 
period of time. PNR is very sensitive to metal stress, and also to slight changes of other physicochemical soil characteristics (for example, pH; Broos et al., 2005). Therefore, PNR rather than SIN was used as a measure of the nitrifying activity for Zn-tolerance testing in the well-defined soil suspensions (that is, constant $\mathrm{pH}$ and ionic strength for all soils) whereas SIN was preferred for screening the nitrification process in field soil samples over time (Broos et al., 2007b). Effects of increasing Zn concentrations to the PNR were related to $\mathrm{Zn}$ concentrations in a $\mathrm{CaCl}_{2}$ soil extract.

DNA extraction, PCR and denaturing gradient gel electrophoresis

DNA was extracted from all soil samples at T0 and T2 in duplicate per soil sample (Mertens et al., 2006). For denaturing gradient gel electrophoresis (DGGE) community profiling, PCR targeting the AOB amoA gene used primers amoA-1F* and amoA-2R (Rotthauwe et al., 1997; Stephen et al., 1999), PCR targeting the AOA amoA gene used primers CrenamoA23f and CrenamoA616r (Tourna et al., 2008). For amplification of AOB amoA genes, $1 \mu \mathrm{l}$ of purified DNA was added to a PCR mixture containing 1.25 U of Taq polymerase (Qiagen, Venlo, the Netherlands), 20 pmol amoA-1F*, 20 pmol amoA-2R, $10 \mathrm{nmol}$ of each dNTP, $1 \times$ PCR buffer (Qiagen), $5 \mu$ l bovine serum albumin (1\%) and PCRgrade water to a total volume of $50 \mu \mathrm{l}$. PCR was conducted in an Eppendorf Mastercycler (Eppendorf, Hamburg, Germany) and PCR conditions were $10 \mathrm{~min}$ at $94^{\circ} \mathrm{C}$, followed by 35 cycles of $60 \mathrm{~s}$ at $94{ }^{\circ} \mathrm{C}, 60 \mathrm{~s}$ at $60{ }^{\circ} \mathrm{C}$ and $60 \mathrm{~s}$ at $72^{\circ} \mathrm{C}$, and a final elongation step for $10 \mathrm{~min}$ at $72^{\circ} \mathrm{C}$. A GC-rich clamp was attached to the $5^{\prime}$ end of the AOB forward primer for DGGE fingerprinting. Analysis of PCR products size and integrity, and DGGE profiling of amplified bacterial amoA gene fragments were performed as described (Mertens et al., 2006). Amplification of AOA amoA genes used Qiagen HotStar Taq PCR chemistry. DGGE separation of the AOA amoA genes was conducted without requirement for a GC-clamp in an Ingeny PhorU DGGE system (Tourna et al., 2008). DGGE profiling was performed as previously described (Nicol et al., 2005; Tourna et al., 2008).

amo $A$ sequence and phylogenetic analysis

Band excision, cloning and sequencing were performed on the unexposed and Zn-exposed soil samples at T2 as described (Mertens et al., 2006). Sequences for dominant bands ' $a$ ' to ' $\mathrm{k}$ ' (Figure 3c) have been submitted to the GenBank database under accession numbers EU515192 through to EU515202. AOB amoA DNA sequences 'a' to ' $\mathrm{k}$ ' had open reading frames with translation products matching known AmoA protein sequences. The sequence data for each clone was compared with sequences on GenBank using the BlastN tool and similar and dissimilar sequences spanning the amoA region of interest were recovered. Sequences were aligned in ClustalX; the alignment was manually checked. Phylogenetic analyses were conducted using MEGA version 4 (Tamura et al., 2004) using the UPGMA method (Sneath and Sokal, 1973) with evolutionary distances computed using the maximum composite likelihood model (Tamura et al., 2007). Phylogeny was tested using bootstrapping (Felsenstein, 1985) with 500 replicates (Supplementary Figure 2).

amo $A$ gene copy and gene transcript quantification Copy numbers of AOB and AOA amoA gene fragments were quantified in all soil samples at T2 and, additionally, in the unexposed and Zn-exposed soil samples at T0, T1 and T3 by real-time quantitative PCR (qPCR) on a Rotor-Gene 3000 Real-time PCR Cycler (Corbett Research, St Neots, UK). Real-time PCR of amoA gene fragments used the primers amoA-1F* and amoA-2R primers as previously described (Rotthauwe et al., 1997; Stephen et al., 1999), and primers Amo196F and Amo277R (Treusch et al., 2005) for AOA. The protocols for quantitative amplification were based on methods described elsewhere (Okano et al., 2004; Treusch et al., 2005). In short, qPCR was performed in $25 \mu \mathrm{l}$ reaction mixtures using $5 \mu \mathrm{l}$ purified DNA as template and $12.5 \mu \mathrm{l}$ of SYBR Green master mix (Qiagen). Primer concentrations were $2.25 \mathrm{pmol}$ for primers amoA-1F* and amoA-2R, $1.5 \mathrm{pmol}$ Amo169F and 3 pmol Amo277R for the AOA amoA amplification. Reaction mixtures were made up to a final volume of $25 \mu \mathrm{l}$ using PCR-grade water. The protocol for amplification of AOB amoA fragments was $2 \mathrm{~min}$ at $50^{\circ} \mathrm{C}, 15 \mathrm{~min}$ at $95^{\circ} \mathrm{C}, 45$ cycles of $45 \mathrm{~s}$ at $95{ }^{\circ} \mathrm{C}, 60 \mathrm{~s}$ at $60{ }^{\circ} \mathrm{C}$ and $45 \mathrm{~s}$ at $72{ }^{\circ} \mathrm{C}$ (based on Okano et al., 2004), and the protocol for amplification of AOA amoA fragments was $15 \mathrm{~min}$ at $95^{\circ} \mathrm{C}, 45$ cycles of $15 \mathrm{~s}$ at $95^{\circ} \mathrm{C}, 40 \mathrm{~s}$ at $55^{\circ} \mathrm{C}$ and $45 \mathrm{~s}$ at $72^{\circ} \mathrm{C}$ (based on Treusch et al., 2005). Both protocols were followed by a final elongation step of $5 \mathrm{~min}$ at $72^{\circ} \mathrm{C}$. Dissociation curve analysis and agarose gel electrophoresis were performed to confirm amplification specificity. Dissociation curves for $\mathrm{AOB}$ and AOA amoA quantification were conducted by stepwise increasing the temperature with $1{ }^{\circ} \mathrm{C}$ from 60 to $95^{\circ} \mathrm{C}$ or 55 to $95{ }^{\circ} \mathrm{C} \mathrm{(45s} \mathrm{at} \mathrm{the} \mathrm{lowest} \mathrm{temperature,} \mathrm{and} 5 \mathrm{~s}$ for each subsequent temperature step). Dilution series of purified PCR products of plasmids (amoA gene of Nitrosomonas europaea ATCC 19718) and fosmid vectors (clone $54 \mathrm{~d} 9$ ) were used as qPCR standards to allow quantification of each target number per sample.

Total soil RNA was extracted from the unexposed and Zn-exposed soil samples at T0 and T2 using the MoBio Soil RNA extraction kit and was treated with DNAse (Promega, Leiden, the Netherlands). cDNA generation and quantification of $\mathrm{AOA}$ and $\mathrm{AOB}$ amoA transcript numbers were performed as described by Leininger et al. (2006). 
Statistical analyses

Dose-response curves were fitted by log-logistic modeling (Doelman and Haanstra, 1989) using the Marquardt method (proc NLIN, SAS 9.1; NC, USA). Significant $(P<0.05)$ inhibitory effects on amoA gene copy and transcript numbers were detected using Student's $t$-tests.

\section{Results}

Zinc contamination of the arable field decreased nitrification with a characteristic log-logistic doseresponse relationship (Figure 1). The $\mathrm{EC}_{50}$ for SIN (effective concentration with $50 \%$ reduction of SIN compared to the unexposed soil sample) was $3.6 \mathrm{mM}$ Zn one week after exposure (T0; Broos et al., 2007b). The $\mathrm{EC}_{50}$ increased significantly to $13.1 \mathrm{mM} \mathrm{Zn}$ after 2 years of exposure (T2). Zinc concentrations in the Spalding soil samples were expressed as $0.01 \mathrm{M}$ $\mathrm{CaCl}_{2}$ soil extracts, which mimic in situ $\mathrm{Zn}$ concentrations in porewater (Degryse et al., 2003) and, hence, bioavailable Zn concentrations in soil (Mertens et al., 2007). A Zn contamination level of $28.3 \mathrm{mmol} \mathrm{Zn}$ per $\mathrm{kg}$ soil, corresponding to $22 \mathrm{mM}$ $\mathrm{Zn}$ at T0 and $6.6 \mathrm{mM} \mathrm{Zn}$ at T2, was the highest contamination level for which ammonia oxidation was restored within 2 years after initial inhibition (Figure 1), and this soil sample was selected for further analysis ('Zn-exposed soil').

Zinc-tolerance testing of the unexposed soil sample at $\mathrm{T} 0$ and $\mathrm{T} 2$ revealed $\mathrm{EC}_{50}$ values of 0.09 and $0.22 \mathrm{~mm} \mathrm{Zn}$, respectively (Figure 2). No nitrifying activity was detected for the Zn-exposed soil sample at T0. Two years after Zn addition, the PNR of the Zn-exposed soil sample was comparable to the PNR of the unexposed soil sample, and application of increasing $\mathrm{Zn}$ doses to the Zn-exposed soil sample at T2 did not affect the PNR (Figure 2).

The AOB and AOA amoA gene copy numbers in the unexposed soil samples did not differ significantly from each other, and were not significantly different between T0 and T2 (Figure 3a). AOA amoA gene copy numbers in the Zn-exposed soil sample were lower than AOB amoA gene copy numbers at both T0 and T2, with a significant difference at T2 (Figure 3a). Also, in the examination of T2 samples exposed to a range of $\mathrm{Zn}$ doses, severe decreases of AOA amoA gene copy numbers were observed at a soluble Zn concentration two orders of magnitude lower than for AOB amoA gene copy numbers (Supplementary Figure 1a).

At T0, the numbers of AOB and AOA amoA gene transcripts in the unexposed soil samples were $3.7 \times 10^{6}$ and $1.2 \times 10^{6}$ perg of soil, respectively, and similar values were found at T2 (Figure $3 \mathrm{~b}$ ). In contrast, the number of AOB and AOA amoA gene transcripts in the Zn-exposed soil samples was more than 3 orders of magnitude reduced at T0, compared to the values in the unexposed soil sample (Figure 3b). After two years of exposure, the number

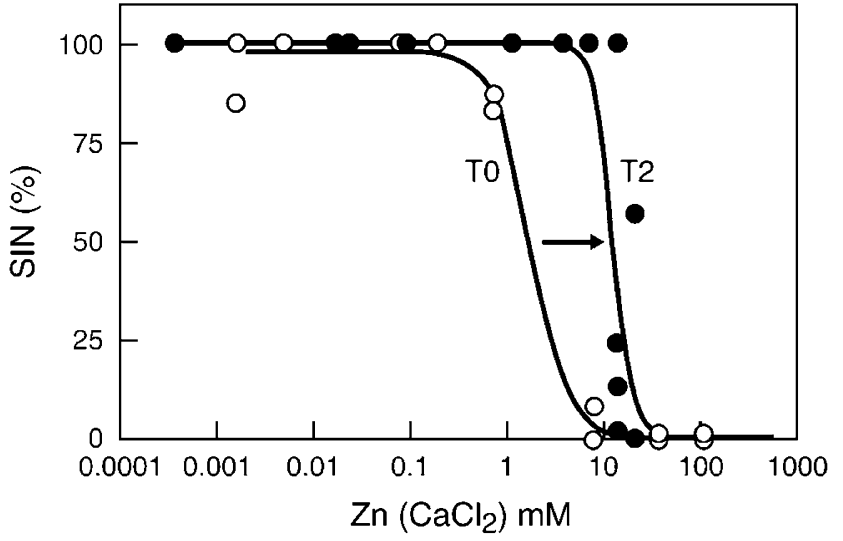

Figure 1 Substrate induced nitrification (SIN) in the Spalding field site over time. SIN, expressed as percentage substrate used $(\%)$, is plotted versus $\mathrm{Zn}$ concentrations in a $0.01 \mathrm{M} \mathrm{CaCl}_{2}$ soil extract at T0 (open symbols) and T2 (closed symbols). The arrow indicates the shift in $\mathrm{EC}_{50}$ (Effect Concentration with $50 \%$ decrease compared to the unexposed soil sample) values between $\mathrm{T} 0$ and $\mathrm{T} 2$.

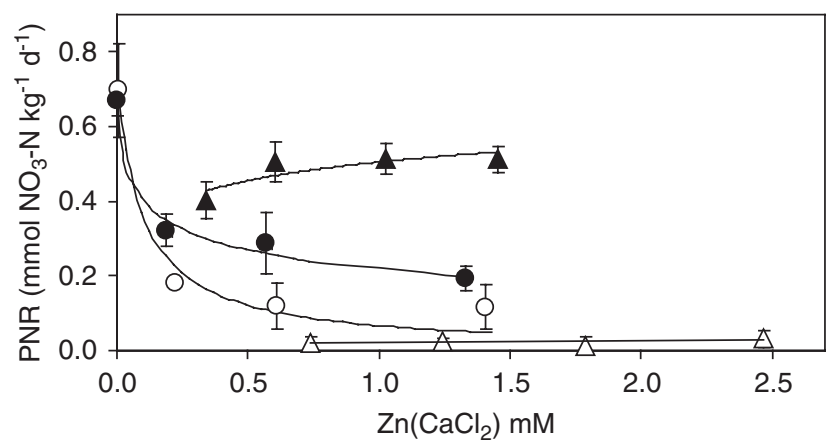

Figure 2 Zn-tolerance testing at T0 and T2. Potential nitrifica-

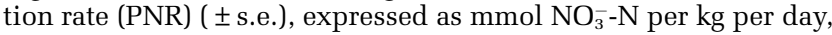
of the unexposed soil sample (circle) and a Zn-exposed soil sample (triangle) at T0 (open symbols) and T2 (closed symbols), is plotted versus $\mathrm{Zn}$ concentrations in a $0.01 \mathrm{M} \mathrm{CaCl}_{2}$ soil extract ( \pm s.e.).

of AOB amoA gene transcripts recovered to the level of the unexposed soil sample at T0, but remained a bit lower than the level of the unexposed soil sample at T2. In contrast, the number of AOA amoA gene transcripts remained 4 orders of magnitude below that in the unexposed soil sample (Figure $3 \mathrm{~b}$ ).

Community profiling of amoA genes (DGGE) showed a distinct shift in the AOB community structure in the Zn-exposed soil samples at T2, yet no such shift in amoA genotypes was observed for the AOA community (Supplementary Figures $1 \mathrm{~b}$ and $\mathrm{c}$ ). In the AOB community profile of the unexposed soil, the amoA genotypes corresponding to bands labeled 'b', 'c', 'd' and 'e' in the DGGE fingerprint were most prevalent (Figure 3c). However, at T2, bands ' $h$ ' and ' $i$ ' were most prominent in the AOB amoA community profile (Figure 3c). Sequence analysis revealed that all detected AOB amoA bands were affiliated with several sequence clusters within 


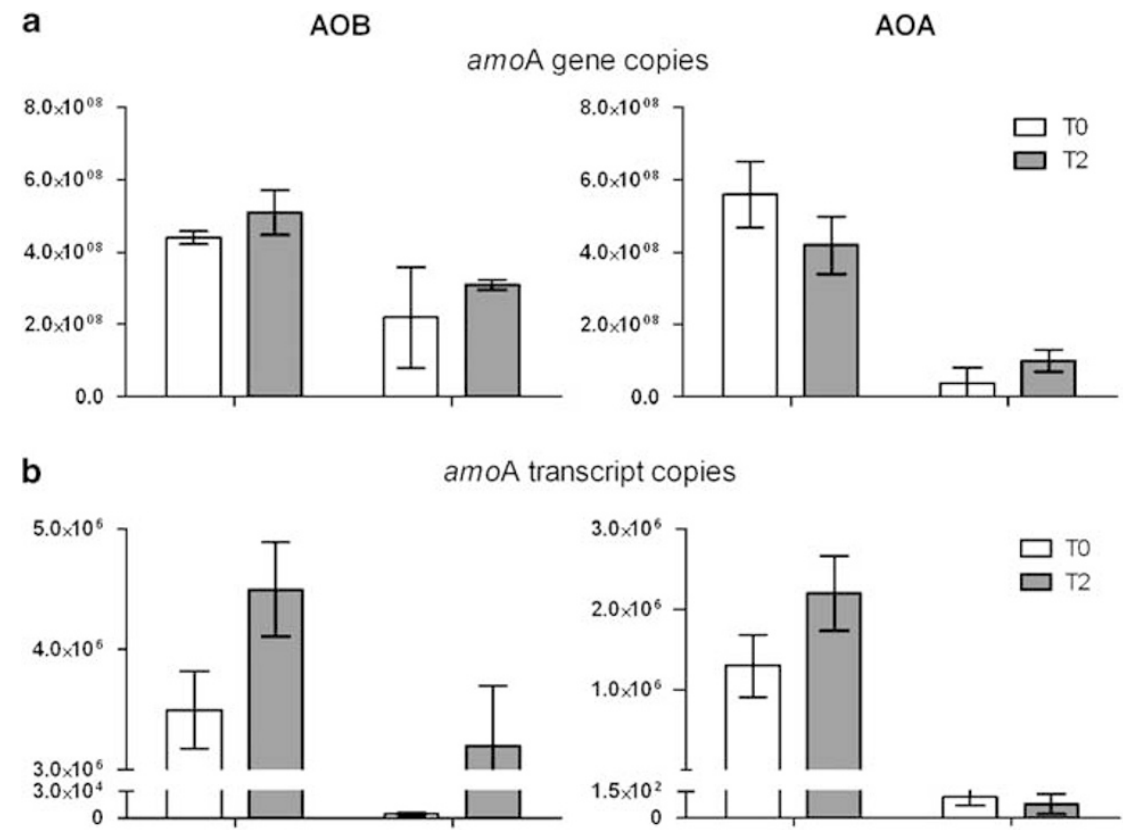

C amoA community profile
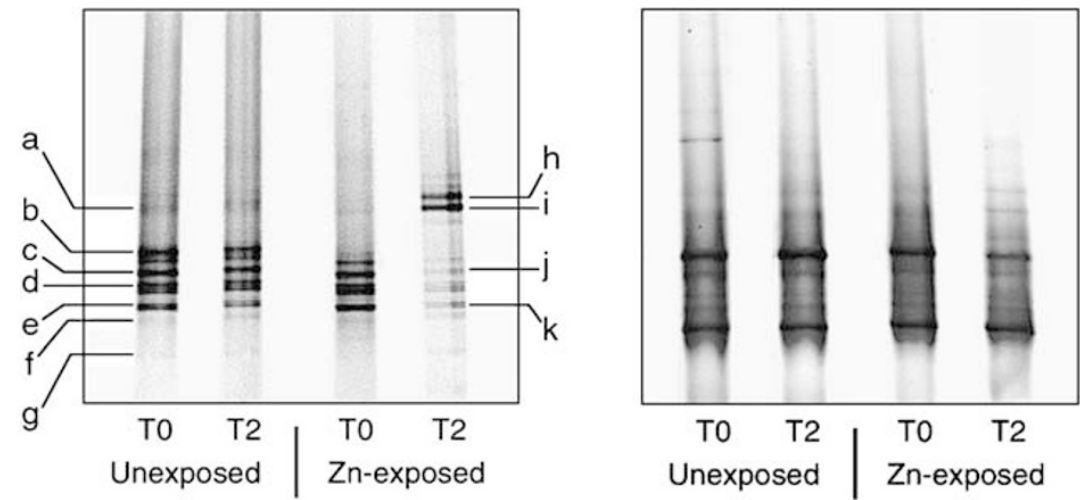

Figure 3 amoA gene copy numbers, amoA gene transcript numbers and amoA community profile of AOB and AOA in the unexposed and the Zn-exposed soil sample over time. Average number of amoA gene copies ( \pm s.e.; a) and number of amoA gene transcripts ( \pm s.e.; b) of two field replicates and the amoA community profile (c) of AOB and AOA in the unexposed soil sample and the Zn-exposed soil sample at T0 and T2. Bands marked with a letter ('a' to ' $k$ ') where cloned and sequenced and belong to the Nitrosospira lineage.

the Nitrosospira lineage (Avrahami et al., 2002), and no clustering of sequences was observed with respect to the $\mathrm{Zn}$ tolerance of the community (Supplementary Figure 2).

\section{Discussion}

The increased $\mathrm{EC}_{50}$ value over time, expressed as $\mathrm{Zn}$ concentrations in $0.01 \mathrm{M} \mathrm{CaCl}_{2}$ soil extracts (Figure 1), was not attributable to slow immobilization reactions of $\mathrm{Zn}$ in soil, but rather to adaptation of the ammonia-oxidizing community, as observed for other long-term Zn contaminated soils (Rusk et al., 2004; Mertens et al. 2006). This was verified by testing for $\mathrm{Zn}$ tolerance in the Zn-exposed soil sample. In accordance to the SIN data, no nitrifying activity was observed in the Zn-exposed soil sample at T0, whereas nitrification levels recovered to the level of the unexposed soil sample at T2. At the same time, the recovery of the nitrification process in this soil sample was accompanied with increased Zn tolerance within the nitrifying community at T2 (Figure 2).

The AOB and AOA amoA gene copy numbers in the unexposed soil sample were high, but comparable to those found in previous studies (Leininger et al., 2006; He et al., 2007). In several recent studies, the number of AOA amoA gene copies in soil exceeded that of AOB (for example, Adair and Schwartz, 2008; He et al., 2007; Shen et al., 2008), whereas numbers in the unexposed Spalding soil were roughly equal. The reduction of the AOA amoA gene copy numbers on contamination is very 
rapid (Figure 3a; Supplementary Figure 1a). All evidence suggests the death of AOA cells on contamination, as storage and rewetting itself does not significantly affect levels of AOA, AOB or total bacteria in these soils (not shown). It should be noted that the coverage of amoA-based primers, especially for AOA, is not yet well established, and the assays used in this study may therefore underestimate actual amoA gene copy and gene transcript numbers. At $\mathrm{T} 2$, the nitrification activity in the $\mathrm{Zn}$-exposed soil sample recovered to the value in the unexposed soil sample (Figures 1 and 2), and AOB amoA gene copy numbers were appreciable (Figure 3a). In contrast, the AOA amoA gene copy number in the Zn-exposed soil sample was fivefold lower compared to the unexposed soil sample (Figure 3a), suggesting that recovery of SIN in the Zn-exposed soil sample was exclusively attributable to the AOB community in this soil. This finding is supported by a tight association between AOB amoA gene copy numbers and SIN across $\mathrm{Zn}$ application rates at $\mathrm{T} 2 \quad(50 \%$ reduction of $\mathrm{AOB}$ amoA gene copy numbers and SIN at $8.1 \mathrm{mM}$ and $13.1 \mathrm{mM} Z \mathrm{Zn}$, respectively, and at $0.07 \mathrm{mM} \mathrm{Zn}$ for the AOA amoA gene copy numbers; Figure 1; Supplementary Figure 1a). SIN, level of Zn tolerance and $\mathrm{AOB}$ and AOA amoA gene copy numbers of the unexposed and the Zn-exposed soil samples at T1 (that is, after 1 year of exposure) were similar to those at T0 and corresponding data at T3 (that is, after 3 years of exposure) were similar to those at T2 (details not shown).

The inhibition of SIN in the Zn-exposed soil sample at T0 coincided with a sharp decrease in the AOB and AOA amoA gene transcript numbers, indicating that both groups were severely affected by $\mathrm{Zn}$ stress (Figures 1 and $3 \mathrm{~b}$ ). The restoration of the nitrification process in the Zn-exposed soil sample at T2 was associated with a recovery of the amoA gene transcript number within the AOB community, but not within the AOA community (Figure $3 \mathrm{~b}$ ), providing evidence for a dominant role of $\mathrm{AOB}$ in the restoration of the ammonium oxidation activity. At the same time, the AOB amoA gene community profile in the Zn-exposed soil sample had changed, yet no corresponding change could be observed within the AOA amoA gene community profile (Figure 3c). As sequence variation in the AOB amoA gene is closely linked to 16S rRNA phylogeny (Purkhold et al., 2000, 2003; Aakra et al., 2001), this observation suggested a shift in AOB community structure that was associated with restoration of nitrification. Interestingly, we did not observe any clustering of recovered sequences with respect to $\mathrm{Zn}$ tolerance of the communities (Supplementary Figure 2). Thus, it appears that the ability to acquire $\mathrm{Zn}$ tolerance is widespread throughout the Nitrosospira lineage, and specific to particular ecotypes not discerned using this functional marker gene. The selection of genotypes of Zn-tolerant AOB species occurred from low background levels of these AOB, or from adaptation and selection of Zn-tolerant AOB over time. Our failure to detect a shift in the AOA community suggested the AOA community did not have the capacity to respond to Zn-induced stress over a 2-year time period. Similar to our results, changes of the numbers of $\mathrm{AOB}$ and AOA amoA gene copies, gene transcripts and/or amoA gene profiles suggested AOB dominated ammonia oxidation in an alkaline sandy loam soil under different long-term fertilization regimes (Shen et al., 2008), in grassland under different grazing managements (Le Roux et al. 2008) and in long-term acidified soil samples (Nicol et al., 2008). In contrast, data on the numbers of $\mathrm{AOB}$ and $\mathrm{AOA}$ amoA gene transcripts in soils incubated at different temperatures (Tourna et al., 2008) and in nitrogen fertilized paddy rhizosphere soils (Chen et al., 2008) suggest an AOA-dominated ammonia-oxidation process. It must be recognized that the nitrification process, amoA gene community profiles, amoA gene copy numbers and amoA gene transcript numbers were analyzed in dried, stored and reconditioned soils. Detected target numbers may therefore not be an accurate portrayal of in situ conditions. However, we have observed that soil drying and storage, which mimic the conditions present for extended periods in these fields (Broos et al., 2007a), had no detectable effects on determined process rates, as well as on bacterial numbers (data not shown). Furthermore, our molecular analyses were geared toward determining the populations responsible for activities in the reconditioned soil samples, not necessarily in situ field conditions at the time of sampling.

Thus, contrary to the general view of archaea being more tolerant to chronic stress conditions than bacteria (Schleper et al., 2005; Valentine, 2007), we demonstrated that AOA were more sensitive to $\mathrm{Zn}$ contamination than $\mathrm{AOB}$ in this soil. It is unlikely that the effects on the AOA community were caused by other physicochemical or biological soil processes besides $\mathrm{Zn}$, as the numbers of $\mathrm{AOA}$ and AOB amoA gene copies and gene transcripts and AOA and AOB amoA gene profiles of the unexposed soil samples were similar across all replicates and sampling times (that is, T0 to T3). Similar consistent results were observed by Wheatley et al. (2003) in three uncontaminated fields. Interestingly, significant numbers of AOA amoA genes still remained in the Zn-exposed soil samples at $\mathrm{T} 2$, even though virtually no expression was observed. Thus, the prospect remains that some AOA populations may be able to survive such stress, in dormant states or as spores (Onyenwoke et al., 2004). Alternatively, these organisms may obtain energy through processes other than ammonia oxidation. Further research will be necessary to determine if AOA have longterm adaptive capabilities in response to heavy metal-induced stress. 


\section{Acknowledgements}

JM received a grant from the Institute for the Promotion of Innovation through Science and Technology in Flanders (IWT-Vlaanderen) for his $\mathrm{PhD}$ research and thanks the Research Foundation-Flanders (FWO-Vlaanderen) for a position as postdoctoral researcher. KB received a postdoctoral fellowship from the Western Australian Water Corporation. S Ruyters provided assistance in real-time PCR gene quantification. We thank M McLaughlin, $D$ Heemsbergen and $M$ Warne and all the members of the National Biosolid Research Program of Australia, particularly the SA members for providing the Spalding soils. We thank $S$ Leininger for providing fosmid clone $54 \mathrm{~d} 9$ and $\mathrm{N}$ Boon for providing cloned amoA genes of Nitrosomonas europaea ATCC 19718. A draft of this article was kindly reviewed by Dr JR Stephen (Australian Genome Research Facility, Adelaide). This is publication number 4513 of the Netherlands Institute of Ecology (NIOO-KNAW).

\section{References}

Aakra Å, Utåker JB, Nes IF. (2001). Comparative phylogeny of ammonia monooxygenase subunit A and 16S rRNA genes of ammonia-oxidizing bacteria. FEMS Microbiol Lett 205: 237-242.

Adair KL, Schwartz E. (2008). Evidence that ammoniaoxidizing archaea are more abundant than ammoniaoxidizing bacteria in semiarid soils of Northern Arizona, USA. Microb Ecol 56: 420-426.

Aoi Y, Masaki Y, Tsuneda S, Hirata A. (2004). Quantitative analysis of amoA mRNA expression as a new biomarker of ammonia oxidation activities in a complex microbial community. Lett Appl Microbiol 39: $477-482$.

Avrahami S, Conrad R, Braker G. (2002). Effect of soil ammonium concentration on $\mathrm{N}_{2} \mathrm{O}$ release and on the community structure of ammonia oxidizers and denitrifiers. Appl Environ Microbiol 68: 5684-5692.

Boyle-Yarwood SA, Bottomley PJ, Myrold DD. (2008). Community composition of ammonia-oxidizing bacteria and archaea in soils under stands of red alder and Douglas fir in Oregon. Environ Microbiol 10: 2956-2965.

Broos K, Macdonald LM, Warne MSJ, Heemsbergen DA, Barnes MB, Bell $M$ et al. (2007a). Limitations of soil microbial biomass carbon as an indicator of soil pollution in the field. Soil Biol Biochem 39: 2693-2695.

Broos K, Mertens J, Smolders E. (2005). Toxicity of heavy metals in soil assesses with various soil microbial and plant growth assays: a comparative study. Environ Toxicol Chem 24: 634-640.

Broos K, Warne MSJ, Heemsbergen DA, Stevens D, Barnes MB, Correll RL et al. (2007b). Soil factors controlling the toxicity of copper and zinc to microbial processes in Australian soils. Environ Toxicol Chem 26: $583-590$.

Chen XP, Zhu YG, Xia Y, Shen JP, He JZ. (2008). Ammoniaoxidizing archaea: important players in paddy rhizosphere soil? Environ Microbiol 10: 1978-1987.

Degryse F, Broos K, Smolders E, Merckx R. (2003). Soil solution concentration of $\mathrm{Cd}$ and $\mathrm{Zn}$ can be predicted with a $\mathrm{CaCl}_{2}$ soil extract. Eur J Soil Sci 54: 149-157.
Doelman P, Haanstra L. (1989). Short- and long-term effects of heavy metals on phosphatase activity in soils: An ecological dose response model approach. Biol Fertil Soils 8: 235-241.

Felsenstein J. (1985). Confidence limits on phylogenies: An approach using the bootstrap. Evolution 39: 783-791.

Francis CA, Beman JM, Kuypers MMM. (2007). New processes and players in the nitrogen cycle: the microbial ecology of anaerobic and archaeal ammonia oxidation. ISME J 1: 19-27.

Francis CA, Roberts KJ, Beman JM, Santoro AE, Oakley BB. (2005). Ubiquity and diversity of ammonia-oxidizing archaea in water columns and sediments of the ocean. Proc Natl Acad Sci USA 102: 14683-14688.

He J, Shen J, Zhang L, Zhu Y, Zheng Y, Xu M et al. (2007). Quantitative analyses of the abundance and composition of ammonia-oxidizing bacteria and ammoniaoxidizing archaea of a Chinese upland red soil under long-term fertilization practices. Environ Microbiol 9: 2364-2374.

Head IM, Hiorns WD, Embley TM, McCarthy AJ, Saunders JR. (1993). The phylogeny of autotrophic ammoniaoxidizing bacteria as determined by analysis of $16 \mathrm{~S}$ ribosomal RNA gene sequences. J Gen Microbiol 139: 1147-1153.

Isbell RF. (1996). The Australian Soil Classification. CSIRO: Collingwood, Victoria, Australia.

Jiang QQ, Bakken LR. (1999). Comparison of Nitrosospira strains isolated from terrestrial environments. FEMS Microbiol Ecol 30: 171-186.

Könneke M, Bernhard AE, de la Torre JR, Walker CB, Waterbury JB, Stahl DA. (2005). Isolation of an autotrophic ammonia-oxidizing marine archaeon. Nature 437: 543-546.

Koops H-P, Purkhold U, Pommerening-Röser A, Timmermann G, Wagner M. (2001). The lithoautotrophic ammonia-oxidizing bacteria. In: Dworkin $\mathrm{M}$ et al. (eds). The Prokaryotes: An Evolving Electronic Resource for the Microbiological Community. Springer: New York, pp 778-811.

Kowalchuk GA, Stephen JR. (2001). Ammonia-oxidizing bacteria: A model for molecular microbial ecology. Annu Rev Microbiol 55: 485-529.

Kowalchuk GA, Stienstra AW, Heilig GHJ, Stephen JR, Woldendorp JW. (2000). Changes in the community structure of ammonia-oxidizing bacteria during secondary succession of calcareous grasslands. Environ Microbiol 2: 99-110.

Le Roux X, Poly F, Currey P, Commeauw C, Hai B, Nicol GW et al. (2008). Effects of aboveground grazing on coupling among nitrifier activity, abundance and community structure. ISME J 2: 221-232.

Leininger S, Urich T, Schloter M, Schwark L, Qi J, Nicol GW et al. (2006). Archaea predominate among ammonia-oxidizing prokaryotes in soils. Nature 442: 806-809.

Mertens J, Degryse F, Springael D, Smolders E. (2007). Zinc toxicity to nitrification in soil and soilless culture can be predicted with the same Biotic Ligand Model. Environ Sci Technol 41: 2992-2997.

Mertens J, Springael D, De Troyer I, Cheyns K, Wattiau P, Smolders E. (2006). Long-term exposure to elevated zinc concentrations induced structural changes and zinc tolerance of the nitrifying community in soil. Environ Microbiol 8: 2170-2178. 
Nicol GW, Leininger S, Schleper C, Prosser JI. (2008). The influence of soil $\mathrm{pH}$ on the diversity, abundance and transcriptional activity of ammonia oxidizing archaea and bacteria. Environ Microbiol 10: 2966-2978.

Nicol GW, Schleper C. (2006). Ammonia-oxidising Crenarchaeota: important players in the nitrogen cycle? Trends Microbiol 14: 207-212.

Nicol GW, Tscherko D, Embley TM, Prosser JI. (2005). Primary succession of soil Crenarchaeota across a receding glacier foreland. Environ Microbiol 7: 337-347.

Okano Y, Hristova KR, Leutenegger CM, Jackson LE, Denison RF, Gebreyesus B et al. (2004). Application of real-time PCR to study effects of ammonium on population size of ammonia-oxidizing bacteria in soil. Appl Environ Microbiol 70: 1008-1016.

Onyenwoke RU, Brill JA, Farahi K, Wiegel J. (2004). Sporulation genes in members of the low G+C Gramtype-positive phylogenetic branch (Firmicutes). Arch Microbiol 182: 182-192.

Purkhold U, Pommerening-Röser A, Juretschko S, Schmid MC, Koops H-P, Wagner M. (2000). Phylogeny of all recognized species of ammonia oxidizers based on comparative $16 \mathrm{~S}$ rRNA and amoA sequence analysis: implications for molecular diversity surveys. Appl Environ Microbiol 66: 5368-5382.

Purkhold U, Wagner M, Timmermann G, PommereningRöser A, Koops H-P. (2003). 16S rRNA and amoAbased phylogeny of 12 novel betaproteobacterial ammonia-oxidizing isolates: extension of the dataset and proposal of a new lineage within the nitrosomonads. Int J Syst Evol Microbiol 53: 1485-1494.

Rotthauwe JH, Witzel KP, Liesack W. (1997). The ammonia monooxygenase structural gene $a m o \mathrm{~A}$ as a functional marker: Molecular fine-scale analysis of natural ammonia-oxidizing populations. Appl Environ Microbiol 63: 4707-4712.

Rusk JA, Hamon RE, Stevens DP, McLaughlin MJ. (2004). Adaptation of soil biological nitrification to heavy metals. Environ Sci Technol 38: 3092-3097.

Schleper C, Jurgens G, Jonuscheit M. (2005). Genomic studies of uncultivated archaea. Nat Rev Microbiol 3: 479-488.

Shen JP, Zhang LM, Zhu YG, Zhang JB, He JZ. (2008). Abundance and composition of ammonia-oxidizing bacteria and ammonia-oxidizing archaea communities of an alkaline sandy loam. Environ Microbiol 10: 1601-1611.

Smolders E, Brans K, Coppens F, Merckx R. (2001). Potential nitrification rate as a tool for screening toxicity in metal-contaminated soils. Environ Toxicol Chem 20: 2469-2474.
Smolders E, Buekers J, Oliver I, McLaughlin MJ. (2004). Soil properties affecting toxicity of zinc to soil microbial properties in laboratory-spiked and field-contaminated soils. Environ Toxicol Chem 23: 2633-2640.

Sneath PHA, Sokal RR. (1973). Numerical Taxonomy The Principles and Practice of Numerical Classification. Freeman: San Francisco, USA.

Stephen JR, Chang YJ, Macnaughton SJ, Kowalchuk GA, Leung KT, Flemming CA et al. (1999). Effect of toxic metals on indigenous soil $\beta$-subgroup Proteobacterium ammonia oxidizer community structure and protection against toxicity by inoculated metal-resistant bacteria. Appl Environ Microbiol 65: 95-101.

Stephen JR, Kowalchuk GA, Bruns MAV, McCaig AE, Philips CJ, Embley TM et al. (1998). Analysis of $\beta$ subgroup proteobacterial ammonia oxidizer populations in soil by denaturing gradient gel electrophoresis analysis and hierarchical phylogenetic probing. Appl Environ Microbiol 64: 2958-2965.

Stephen JR, McCaig AE, Smith Z, Prosser JI, Embley TM. (1996). Molecular diversity of soil and marine $16 \mathrm{~S}$ rRNA gene sequences related to beta-subgroup ammonia-oxidizing bacteria. Appl Environ Microbiol 62: 4147-4154.

Tamura K, Dudley J, Nei M, Kumar S. (2007). MEGA4: Molecular Evolutionary Genetics Analysis (MEGA) software version 4.0. Mol Biol Evol 24: 1596-1599.

Tamura K, Nei M, Kumar S. (2004). Prospects for inferring very large phylogenies by using the neighbor-joining method. Proc Natl Acad Sci USA 101: 11030-11035.

Tourna M, Freitag TE, Nicol GW, Prosser JI. (2008). Growth, activity and temperature responses of ammonia-oxidizing archaea and bacteria in soil microcosms. Environ Microbiol 10: 1357-1364.

Treusch AH, Leininger S, Kletzin A, Schuster SC, Klenk H-P, Schleper C. (2005). Novel genes for nitrite reductase and Amo-related proteins indicate a role of uncultivated mesophilic crenarchaeota in nitrogen cycling. Environ Microbiol 7: 1985-1995.

Valentine DL. (2007). Adaptations to energy stress dictate the ecology and evolution of the Archaea. Nat Rev Microbiol 5: 316-323.

Venter JC, Remington K, Heidelberg JF, Halpern AL, Rusch D, Eisen JA et al. (2004). Environmental genome shotgun sequencing of the Sargasso Sea. Science 304: 66-74.

Wheatley RE, Caul S, Crabb D, Daniell TJ, Griffiths BS, Ritz K. (2003). Microbial population dynamics related to temporal variations in nitrification in three arable fields. Eur J Soil Sci 54: 707-714.

Supplementary Information accompanies the paper on The ISME Journal website (http://www.nature.com/ismej) 